\title{
Estimating the Indicators of Financial Development and Their Impact on Financial Indicators of the Main Sectors in Amman Stock Exchange during the Period [2000-2016]
}

\author{
Ateyah Mohammad Alawneh \\ Department of Business Economics, faculty of Business Administration, Tafila Technical University, Jordan
}

Copyright $\bigcirc 2019$ by authors, all rights reserved. Authors agree that this article remains permanently open access under the terms of the Creative Commons Attribution License 4.0 International License

\begin{abstract}
The study aims at estimating the indicators of financial development and their impact on financial indicators of the main sectors in Amman Stock Exchange. The study found that there is no statistically significant impact among the following indicators of financial development [total private credit on Gross domestic product [GDP] and total deposits to GDP], the main sector indices [insurance sector index, services sector index, banking sector index, industry sector index, and general index of Amman Stock Exchange], While the analysis revealed a positive statistically significant effect between the index of financial development [the ratio of the value of shares traded in the financial market to GDP] and the main sectors indicators [insurance sector index, service sector index, banking sector index, industry sector index, and general index of Amman Stock Exchange]. However, the analysis revealed a negative statistically significant impact between the index of financial development liquidity index (LMI) and the main sectors indicators. There was also a significant negative impact between the index of financial development total Monetary index (TMI) and the indicators of the main sectors accept the insurance sector index.
\end{abstract}

Keywords Financial Market Indicators, Financial Development, Financial Market, Financial Indicators of the Main Sectors

\section{Introduction}

The financial development is considered one of the most important elements of the state and has a key role in affecting financial and economic variables, financial markets, and indicators of these markets specially those of the main sectors. According to the fact that the growth of financial indicators leads to economic development which increases the growth of economic sectors, that reflects the indicators of the financial market's sectors through the growth of its value. Moreover, the financial development is essential, especially in developing countries such as Jordan which considered the most needed for such development for the purpose of its growth and affecting the growth of its main sectors. Therefore, this study has been conducted in terms of estimating indicators of financial market though a financial variable's ratio to an economic variable for each indicator of the financial development which is characterized in the following items; [total monetary index, monetary liquidity index, value of shares traded in the financial market to GDP, total private credit index to GDP and the index of total deposits to GDP]. As well as, this study estimated the effect of these indicators on the indicators of the main industry sectors of the companies contained in Amman Stock Exchange. This study also stresses at the understanding the correlation between indicators for the financial development and the indicators of the companies' sectors contained in Amman Stock Exchange, which include [insurance sector index, service sector index, banking sector index, industry sector index, and general index for Amman Stock Exchange].

\subsection{Problem of the Study}

The problem lays in the reality of Jordan, as a surrounding nature; in terms of adopting fiscal and monetary policies to promote sectors in Jordan; in order to reflect the indicators of financial market, which considered as a type of development, that should represent development and growth of financial market, as the main industrial indicators of companies listed in Amman Stock Exchange. Therefore, this study intended to assess the 
indicators of financial development in Jordan, and whether these indicators have a role in influencing the indicators of the main sectors in Jordanian financial market. Thus, the problem of the study can be summed up by the following question following: the indicators of financial development [total monetary index, monetary liquidity index, ratio of shares traded in the financial market to GDP, total private credit index to GDP and total deposits to GDP index], also the indicators of the main sectors [Insurance Sector Index, Services Sector Index, Banks Sector Index, Industry Sector Index and Amman Stock Exchange Index].

\subsection{Study Hypothesis}

The hypothesis of the study can be formulated by the following; there is a statistically significant positive correlation between the indicators of financial development [total monetary index, monetary liquidity index, ratio of shares traded in the financial market to GDP, total private credit index to GDP and total deposits to GDP, and other main indicators such as [Insurance Sector Index, Services Sector Index, Banks Sector Index, Industry Sector Index, and General Index in the Amman Financial Market].

\section{Theoretical Framework and Previous Studies}

\subsection{Previous Studies:}

- The study of [Ndlovu, Godfrey. 2013] is based on examining causal correlation between financial development and econ

- omic growth in Zimbabwe, where the study found a causal correlation between the economic growth and the development of the financial system in Zimbabwe.

- The study of [Charles Wait and Tafadzwa Ruzive. 2016], aims at finding the correlation between financial development and economic growth. The analysis of the study showed that there is a positive correlation between the indicators of financial development, private sector credit to GDP, economic growth, financial depth that current countries are experiencing this, compared to other developing countries.

- The study [Léonce Ndikumana, 2003] aims at finding the impact of the financial structure and financial development on domestic investment. The analysis of the study showed that the financial structure has no independent impact on investment, meaning that it does not enhance the investment response to changes in production, while financial development makes investment more responsive to growth. One of the main recommendations of the study was that countries should strengthen a particular type of financial structure, policies that reduce transaction costs in financial intermediation and this will facilitate the development of banks and stock markets, which will stimulate domestic investment.

- The study of [Hami Mahyar, 2017] aims investigating the effect of inflation on the indicators of financial development in Iran using seasonal data during the period 2000-2015. Where the statistical analysis of the study showed that inflation negatively affects the financial depth and has a significant positive impact on the proportion of total deposits of GDP in banking system in Iran.

- The study of [George Adu, George Marbuahand Justice Tei Mensah. 2013] aims at examining the impact of financial development on growth in Ghana. The statistical analysis of the study showed the impact of indicators of financial development of private sector as a percentage of GDP, as the total domestic credit stimulates growth, while the study found that the index of total liquidity (M2 / GDP) does not stimulate growth.

- The study of [Musharavati Ephraim Munyanyi] searches in the causal correlation between financial development and economic growth in Zimbabwe, as well as the study included the data from 1965 until 2015.

The study concluded that the financial development through which the development of demand for bank deposits in the country is made and one of the most important recommendations of the study that the Government of Zimbabwe should direct its policies towards enhancing its economic performance in order to strengthen and develop the financial sector in this process.

\begin{tabular}{l}
\hline -Total Monetary index [TM]. \\
Monetary Liquidity Index [LMI--Ratio \\
of shares value traded in financial \\
market to GDP. [TSPGD] \\
-Total credit to gross domestic product \\
[FCGDP] \\
-Total deposits to gross domestic product \\
[TDGDP]
\end{tabular}

Figure 1. Independent variables and dependent variables 
- The study of [Andrés Fernández César E.2015] searches in reducing the costs of transaction at institution which leads to enhance development in financial market through the impact of these institutions on financial development and growth, moreover, the study reviews empirical evidences of measuring the impact of institutions on growth through financial development.

- The study of [Dyna Heng, Anna Ivanova, Rodrigo Mariscal, Uma Ramakrishnan, and Joyce Cheng Wong. 2016] searches the state of financial development in Latin America and the Caribbean (LAC), as well as the potential results of growth and stability. The analysis shows that the analysis shows that financial institutions have expanded significantly in the past decade in the Caribbean region (LAC) compared to other developing market areas. The study also notes that the region is lagging behind its peers in financing and financial development, especially in terms of markets, financial systems in many Latin American and Caribbean countries, furthermore these countries are considered as underdeveloped, especially in the macroeconomic area, and need further financial development.

- The study of [Sibel Balı Eryiğit, Kadir Yasin Eryiği and Ercan Dülgeroğlu. 2015] aims at explaining the reasons for the gaps in financial development among governorates in Turkey on capital accumulation based. The study found that the level of social capital leads to financial development in addition to the role of physical and human capitals in the process of financial development in the provinces of Turkey, the study also found that the accumulation of capital contributed more not only to financial development in the provinces, but also to the surrounding area as well.

- The study of [Laura Alfaro, Sebnem Kalemli-Ozcan and Selin Sayek. 2009] indicates a positive correlation between developed financial markets and FDI earnings. Since the development of the financial markets leads to foreign investment on large profits, the study suggests that this development improves local conditions, which should have the dual effect of attracting foreign investment and maximizing benefits of this investment, the thing that will necessarily improve the economy of the country.

- The study of [Evans Ochoroolonje. 2014] aims at explaining the effect of the development of financial market on economic growth, considering that this development is characterized in such indicators; as the interest rate, loans in financial institutions, and the ratio of credit to the private sector to levels of GDP. The study focuses on the five official member countries Kenya, Uganda, Tanzania, Rwanda and Burundi (EAC) between 2008 and 2013, also it should be noted that the secondary data were collected for six years. The results of the study indicate that indicators of financial development explain only $19.4 \%$ of the changes in economic growth in EAC. The study also showed positive relationships between market value, financial development and economic growth. Whereas, statistical analysis showed the negative correlation between the ratio of credit to the private sector to GDP and index of loans in financial institutions, in addition to interest rate with economic growth.

- The study of [Sephooko I. Motelle. 2011] aims at finding an experimental model of workers 'remittances' role on financial development and it has been declared that they have a long-term impact on financial development, as well as, the study shows the impact of inflation and commercial openness have had a short and long- term impact on financial development. Whereas, fiscal liberalization and GDP have a long-term effect only on financial development. This study is looking for figuring suitable environment for increasing remittances and thus positively affecting the financial sector.

- The study of [Nahla Samargandi, Jan Fidrmuc and Sugata Ghosh] aims at clarifying the correlation between financial development and economic growth in 52 middle-income countries during the period 1980-2008. The study was based on simple linear analysis but the study did not find a relationship. Therefore, the study found a statistically significant correlation between financial development and economic growth in the long and short term, in addition that the middle-income countries face poor distribution of economic growth after financial development phase.

- The study of [Abdulsalam Abubakar, Ibrahim Musa Gani. 2013] aims to test the correlation between the long-term financial development and the economic growth in Nigeria from [1970] until [2010]. The study concluded to positive correlation between the liquidity of commercial banks and economic growth, as well as, trade openness and economic growth. Furthermore, statistical analysis of the study showed a statistically significant negative relation between credit facilities of private sector, interest rate, government expenditure and economic growth. The study produced some recommendations, including the development of policy tools to support growth and reduce government importing from the financial sector.

\subsection{Characteristics of the Study}

This study differs from previous studies in the following characteristics:

First, it is one of the few studies in the Arab environment 
and the first in Jordan - according to the researcher - which is concerned with estimating indicators of financial development in Jordan and its effects on the indicators of Amman Stock Exchange. Second, it is one of the few international studies - according to the researcher - which tried to search in the impact imposed by indicators of financial development on market's indicators, since most of the studies on this subject have focused on the impact of financial development on economic growth, considering the fact that there is a circular correlation between indices of financial market and others of financial development. Thirdly, it is the first study - to the best of the researcher's knowledge - which uses multiple linear regression method, using the E-views program to study the effect of independent variables (total monetary index, liquidity index, share of financial market shares to GDP, Private sector credit index on the variables of the insurance sector index, the service sector index, the industry sector index, the banking sector index and the general index of Amman Stock Exchange. Fourth, Previous studies have contained some independent indicators of financial development and did not contain indicators such as [ratio of shares value traded in financial market to GDP, total deposits to GDP], as well as dependent variables in previous studies.

\section{3.Theoretical Framework}

\subsubsection{Indicators of Financial Development in Jordan during Years of the Study}

\subsubsection{Total Monetary Index [TMI]}

This indicator can be measured by the ratio of supplying monetary to GDP in the generalized concept, as well as measuring the ratio of monetary flowing in economics; the intention of that variable is reviewing the true size of the financial sector in a developing economy in which monetary provides savings in the payment of value. As the rise in the ratio leads to the development of financial sector where other financial instruments are not included in the monetary supply, grow in the narrow sense and become increasingly available (Mohamed Abdel Karim Bogaza, 2015). According to the annex [3], the researcher notable that the index is almost constant in Jordan, where the average of indicator is [1.22] during the years of study. As we can notice from the Figure (2), the highest value of the indicator was in (2005); due to the raise of fund presentation in a wide range related to the GDP, but the lowest value of the indicator was in (2012); due to the fall of fund presentation in a wide range related to the GDP.

This supposed to state that the increase in the monetary supplying in broad sense to GDP shall lead to the development in economic activity because of the components of the monetary supply in generalized concept; deposits of all types that lead to increased funds ready for lending in banks and the subsequent increase in investment and then economic activity for sure, therefore, the increase in the activity of financial market, which necessarily increases indicators of financial market.

\subsubsection{Monetary Liquidity Index [LMI]}

This indicator can be measured through the ratio of monetary supply in broad sense to the monetary supply in the narrow concept. As this ratio is directly linked to the level of the financial depth of the state, considering that the development of financial system increases savings deposits faster than monetary transaction balances. This indicator reflects the progress of the financial markets and how they managed to fulfill savings, especially in the banking sector. According to annex [1], the researcher note that the index is almost constant in Jordan, where the average index [3.32] during the years of study.

The researcher can notice from the Figure (2) that the highest rate of the indicator was in (2001); due to the raise of the fund presentation related to the GDP, while the lowest value of the indicator was in (2005); due to the fall of fund presentation in a wide range related to the GDP.

This is supposed to state that the increase the monetary supply in the broad sense that lead to increased economic activity due to deposits of all types are considered one of the components of monetary supply in broad sense which increases funds that are ready for lending in banks, the thing that would necessarily increase investments, economic activity, financial market and its indicators for sure.

\subsubsection{Ratio of Shares Value Traded in Financial Market to GDP. [TSPGD]}

This indicator measures the total value of traded shares of listed companies as a percentage of GDP as well as the degree of market liquidity. According to annex [3], it can be notable that the average index is [0.47] during the years of the study. As the researcher can notice from the Figure (2) the highest value of the indicator was in (2005); due to the raise of shares of the listed companies related to the GDP, but the lowest value of the indicator was in (2000); due to the fall of shares of the listed companies related to the GDP, which indicates an increase in the economic activity due the increase of total value of traded shares of listed companies then the activity of financial market and its indicators necessarily. Which construct a life circle for financial market.

\subsubsection{Total Credit to Gross Domestic Product [FCGDP]}

This indicator can be measured by the ratio of total credit to GDP. Recent theoretical and empirical researches have shown the significant role of credit in supporting private sector investment. Moreover, studies confirmed that the loans directed to the private sector promote investment and productivity growth, on a larger scale than public sector. According to the annex [3] it is notable that the average index [0.88] during the years of study. As The researcher 
notice from the Figure ( 2) that the highest value of the indicator was in (2007); due to the raise of the insurance related to the GDP, while the lowest indicator value was in (2003); due to the fall of the insurance capacity related to the GDP, which express the fall of the GDP indicator. This supposed to state that the increase in credit directed to the private sector according to GDP, would improve economic activity, investments, financial market and necessarily its indicators.

\subsubsection{Total Deposits to Gross Domestic Product [TDGDP]}

Total deposits to gross domestic product can measure this indicator. In other words, the increase of this indicator reflects the increase of deposits from financial savings to gross domestic product [GDP], furthermore, it's considered the main source of investment finance, leading to increased growth. According to annex [3], it is notable that the average of the indicator is [0.75], during years of the study. The researcher can notice from the Figure (2) that the highest rate of the indicator was in (2015); due to the raise of the deposits related to the GDP, which means the raise of the money development, but the lowest indicator value was in (2013); due to the fall of the deposits related to the GDP, which express the fall in the GDP indicator. This is supposed to state that the increase in deposits in relation to the gross domestic product can lead to an increase in economic activity. Moreover, deposits of all types could make an increase in funds ready for lending in banks and consequently increased investment, economic activity, financial market and necessarily its indicators.

\subsection{Major Sector Indices on the Amman Stock Exchange}

Indices are considered as the most important indicators for levels of shares prices and it determines the general direction of prices, as well as it's commonly used for measuring changes that may affect shares prices during a period of time comparing to another. These indices are calculated based on the latest closing prices available to the companies included in the sample, and these figures are published on a daily basis. Furthermore, and in order to enable the index to reflect the true picture of the changes in the prices of shares owned by the listed companies in stock shares, also it should be noted that the sample is reviewed periodically every 3 months by studying the activity of companies listed on the stock exchange to add active companies to the sample and withdraw inactive ones. The study will adopt the weighted average index of free shares for the main sectors of the Amman Stock Exchange; because it's the best presenter of stock prices movements in stock shares, to ensure that it does not judge biased to companies with high market value, thus providing diversification in the components of the index sample by giving greater opportunities for SMEs to influence its movements despite the existence of other record numbers in Amman Stock Exchange. This figure has the advantage in reflecting better variation in shares price, as well as it reduces the impact of great market value companies In addition, it gives greater opportunity for SMEs to influence its movements. (https://www.ase.com.jo/ar/node/820)

The sample of these indicators consist of the listed companies in Amman Stock share for any of the sectors, and the sample is chosen by experts, who have the experience in calculating the main sectors in Amman Stock Share; whereby the indicators are calculated based in the general ideal number law in the free shares listed in Amman stock share for any sector. Therefore, it is noted from appendix (4) and the Figure ( 3 ) the following points:

\subsubsection{Insurance index [AMIX]}

The average of Insurance index has amounted to [2389] during the years of study, in [2005] amounted to [5,388.65]; due to the increase in investment activity, especially by investors in neighboring countries as a result of economic and political stability, also the increase in investment's volume and trading. Unlike the lowest value in [2000], which amounted to [920.35]; due to the decline in investment activity in the financial market, as a result for economic instability in Jordan investments compared to [2005].

\subsubsection{Services Sector Index [AMSX]}

The average of services sector index has amounted to [1682.64] during the years of study. Also it has been at the summit in [2007] with a value of [2,460.32], due to the increase in investment activity in the services sector as a result of improvements in industrial activity, banks, insurance and general index in Amman Stock Exchange, which needs more services and development in this sector, prompting investors to this sector for market needs, especially by investors in countries As a result of the economic and political stability and the increase in the volume of investment and trading, either the lowest value was in 2000, which amounted to [915.1]; as a result , to the decline in investment activity in the financial market and the economic instability in Jordan comparing to [2005] in other investment activities such as industry, banks, insurance and general index of Amman Stock Exchange.

\subsubsection{Banks Sector Index [AMBX]}

The average of banks sector indicator has amounted to [473494] during years of the study and it has reached the summit in [2005] with an amount of [6,171.34]; due to the increase in investment activity, especially by investors in neighboring countries as a result of economic and political stability as well as, increased volume of investment and trading. However, the lowest value in 2000, which amounted to [774.24]; which is considered as a result to the decline in investments in the financial market, economic instability in Jordan, also the decline in investment activity compared to [2005]. 


\subsubsection{Industry Index [AMIDX].}

The average of industrial sector index has reached [2066.86] the highest value of the industrial sector index was in 2005 [2,815.60]; due to the increase in investment, especially by investors in neighboring countries, economic and political stability, However the lowest value in [2000] was [774.24] as a result to the decline in investments financial market; because of economic instability in Jordan.

\subsubsection{Stock Exchange Index [AMGNRLX]}

The overall average of Amman Stock Exchange Index was [2256.15] during years of the study, also it has reach the highest value in [2005]; due to the increase in investment, especially by investors in neighboring countries, economic and political stability. The studies have shown that Amman Stock Exchange have had a great profit have not been recorded yet; where the trading ratio has reached exceptional levels since the establishment of stock shares, until it reaches [16871] million JD, comparing to the [3793.2] million JD in 2004, with an increase of [\% 344.7]. The total number of shares traded reached 2582.6 million shares, an increase of 93\% compared with the number of shares traded during [2004] at 1338.7 million shares. Considering that the number of executed contracts reached [2.392] million during [2005] with a growth rate of [103\%] compared to the number of [1.178] million in 2004, with [1.178] million contracts and the daily average volume has increased to [69.1] million JD with growth of [\% 348.7] Compared to the daily average volume of trading during [2004] which reached [15.4] JD million. As well as, the number of companies listed on Amman Stock Exchange rose to 2001 compared to 196 in 2004 (Sabri Al-Khasib, 2006). However, the lowest value in 2000 was [813.34]; due to the decline in investment in financial market because the economic instability in Jordan and neighboring countries.

\subsection{The Relationship between Financial Development and Indicators of Different Sectors}

Some studies also note that reform in the banking sector is reflected in the financial market indicators of the interrelationship between the banking sector and financial markets (Abdul salam Abu bakar, Ibrahim Musa Gani, 2013) also previous studies show that there is a direct and indirect relationship between financial markets and indicators of financial development, which include the main sectors of the financial markets As a study Mohamed Abdel Karim Bogaza, (2015), Abdul salam Abu bakar, Ibrahim Musa Gani (2013), Andrés Fernandez César E. (2015), Charles Wait and Tafadzwa Ruzive, (2016), the relationship between the indicators of financial development and the financial markets is indicated by the impact of financial development indicators on economic growth, which is reflected through the financial markets by achieving growth in the main sectors of the financial markets.

The researcher points out The South African experience used various elements of financial development to support economic growth, leading to the growth of all major sectors (industry, services, insurance and banking), which was reflected in the major sector indices in the financial markets. (Abdul salam Abu bakar, Ibrahim Musa Gani,2013) also mode (Greenwood and Jovanovich ,1990) which refers to the role of financial development in providing support to the main economic sectors (industrial, service, insurance and banks) (Abdul salam Abu bakar, Ibrahim Musa Gani, 2013)

As the study shows (Mohammed Issa Shehatait, Saud Mousa Al-Tayeb and Qusay Mohammed Al-Tarouna, 2014) one-way causal relationship, moving from investment to the Amman financial market, and the existence of causal relationships A one-way is moving from volume trading in both the financial and services sectors to investment also study of Abu-Ghazaleh (1991), which focused on the possibility of determining the nature of the relationship between financial development and real developments in Jordan, the study showed that the financial depth has positive effects on investment, savings and economic growth (Mohammed Issa Shehatait, Saud Mousa Al-Tayeb and Qusay Mohammed Al-Tarouna, 2014) where the indicators of financial development total monetary index [TMI], Monetary liquidity index [LMI), total credit to gross domestic product [FCGDP] and total deposits to gross domestic product [TDGDP]. These indicators provide funds for investment in the sectors (industrial, services, insurance, banks) and positively reflect the response of the main sector indicators in the financial market.

The researcher can conclude that the financial development indicators affect the financial markets, which is the financial market as a reflection of the economic activity in the country, in the sense that the increase in financial indicators lead to an increase in the indices of the main sectors of the financial market and vice versa.

\section{The Models of the Study}

The multi-linear regression method and the E-views software will be adopted to examine the effect of the independent variables on the main sector indices in the ASE as follows.

\subsection{AMIX f(TMI, LMI , TSGDP , CFGDP ,TDGDP)}

[AMIX]: Amman monetary insurance index during study years.

[TMI]: Total monetary index and it's calculated as (M2/GDP) during study years.

[LMI]: monetary liquidity index and it's calculated as (M2/M1) during study years. 
[TSGDP]: ratio of shares value traded in financial market to GDP during study years.

[TDGDP]: traded deposits gross domestic product during study years.

Consequently, the multiple regression equation can be written according to the following formula:

LOG AMIX = a + B1LOG(TMI) + B2 LOG(LMI) + B3

LOG(TSGDP)+B4LOG(CFGDP)+B5 LOG(TDGDP) +E

Where $\mathrm{B} 1, \mathrm{~B} 2, \mathrm{~B} 3, \mathrm{~B} 4$ and $\mathrm{B} 5$ are the regression coefficients of the independent variables whose signals can determine direction of the correlation between the independent variables and the dependent variable $\mathrm{E}$ : Standard errors.

\subsection{AMSX $=\mathrm{f}$ (TMI, LMI , TSGDP , CFGDP ,TDGDP)}

Where [AMSX]: Amman Service Sector Index during study years.

Consequently, the multiple regression equation can be written according to the following formula:

LOG AMSX = a + B1LOG(TMI) + B2 LOG(LMI) + B3 LOG(TSGDP)+B4LOG(CFGDP)+B5 LOG(TDGDP) +E

3.4 $\mathrm{AMBX}=\mathrm{f}$ (TMI, LMI , TSGDP , CFGDP ,TDGDP)

[AMBX]: Amman banking index, during study years.
Consequently, the multiple regression equation can be written according to the following formula:

$$
\begin{array}{r}
\text { LOG AMBX }=\mathrm{a}+\mathrm{B} 1 \mathrm{LOG}(\mathrm{TMI})+\mathrm{B} 2 \mathrm{LOG}(\mathrm{LMI})+ \\
\text { B3LOG(TDGDP) +B4LOG(CFGDP)+B5 LOG(TSGDP) } \\
+\mathrm{E}
\end{array}
$$

3.5. AMIDX $=\mathrm{f}$ (TMI, LMI , TSGDP , CFGDP ,TDGDP)

Where: [AMIDX]: Amman Industry Index, during study years.

Consequently, the multiple regression equation can be written according to the following formula:

LOG AMIDX $=\mathrm{a}+\mathrm{B} 1 \mathrm{LOG}(\mathrm{TMI})+\mathrm{B} 2 \mathrm{LOG}(\mathrm{LMI})+\mathrm{B} 3$ LOG(TSGDP)+B4LOG(CFGDP)+B5 LOG(TDGDP) +E

3.6. AMGNRLXf(TMI, LMI , TSGDP, CFGDP ,TDGDP)

Where [AMGNRLX]: general index of Amman Stock Exchange, during study years.

Consequently, the multiple regression equation can be written according to the following formula:

LOG AMGNRLX $=\mathrm{a}+\mathrm{B} 1 \mathrm{LOG}(\mathrm{TMI})+\mathrm{B} 2 \mathrm{LOG}(\mathrm{LMI})+\mathrm{B} 3$ LOG(TSGDP)+B4LOG(CFGDP)+B5 LOG(TDGDP) +E

The data were analyzed using E-views software. The results of the analysis were as it's described below: 

of the Main Sectors in Amman Stock Exchange during the Period [2000-2016]

Table 1. Estimating the Indicators of Financial Development and Their Impact on Financial Indicators of the Main Sectors in Amman Stock Exchange

\begin{tabular}{|c|c|c|c|}
\hline \multicolumn{4}{|c|}{ Modal (1) Dependent Variable: LOG( AMSX ) } \\
\hline Variable & Coefficient & t- Statistic & Prob \\
\hline LOG(TMI) & -1.003471 & -1.130151 & 0.2825 \\
\hline LOG(LMI) & -3.670400 & -3.268979 & 0.0075 \\
\hline LOG(TSGDP) & 0.244526 & 3.667816 & 0.0037 \\
\hline LOG(CFGDP) & 0.938004 & 1.127130 & 0.2837 \\
\hline LOG(TDGDP) & 0.779109 & 0.843067 & 0.4171 \\
\hline $\mathrm{C}$ & 12.96744 & 10.08106 & 0.0000 \\
\hline \multicolumn{4}{|c|}{ Modal (2) Dependent Variable: LOG( AMSX ) } \\
\hline Variable & Coefficient & t- Statistic & Prob \\
\hline LOG(TMI) & -2.207642 & -3.067038 & 0.0107 \\
\hline LOG(LMI) & -2.144947 & -2.356536 & 0.0380 \\
\hline LOG(TSGDP) & 0.145083 & 2.684463 & 0.0212 \\
\hline LOG(CFGDP) & 0.565239 & 0.837838 & 0.4200 \\
\hline LOG(TDGDP) & 0.752131 & 1.003958 & 0.3370 \\
\hline $\mathrm{C}$ & 10.86271 & 10.41715 & 0.0000 \\
\hline \multicolumn{4}{|c|}{ Modal (3) Dependent Variable: LOG( AMSX ) } \\
\hline Variable & Coefficient & t- Statistic & Prob \\
\hline LOG(TMI) & -4.042785 & -3.075476 & 0.0106 \\
\hline LOG(LMI) & -7.116837 & -4.281400 & 0.0013 \\
\hline LOG(TSGDP) & 0.143308 & 1.451953 & 0.1744 \\
\hline LOG(CFGDP) & 1.052662 & 0.854394 & 0.4111 \\
\hline LOG(TDGDP) & 0.916210 & 0.669667 & 0.5169 \\
\hline $\mathrm{C}$ & 17.99731 & 9.450599 & 0.0000 \\
\hline \multicolumn{4}{|c|}{ Modal (4) Dependent Variable: LOG( AMSX ) } \\
\hline Variable & Coefficient & t- Statistic & Prob \\
\hline LOG(TMI) & -3.293615 & -3.038166 & 0.0113 \\
\hline LOG(LMI) & -3.206076 & -2.338727 & 0.0393 \\
\hline LOG(TSGDP) & 0.234914 & 2.886015 & 0.0148 \\
\hline LOG(CFGDP) & 0.305936 & 0.301098 & 0.7690 \\
\hline LOG(TDGDP) & 0.223217 & 0.197832 & 0.8468 \\
\hline $\mathrm{C}$ & 12.51669 & 7.969811 & 0.0000 \\
\hline \multicolumn{4}{|c|}{ Modal (5) Dependent Variable: LOG( AMSX ) } \\
\hline Variable & Coefficient & $\mathrm{t}$ - Statistic & Prob \\
\hline LOG(TMI) & -1.617768 & -1.645831 & 0.1280 \\
\hline LOG(LMI) & -3.911515 & -3.146887 & 0.0093 \\
\hline LOG(TSGDP) & 0.193764 & 2.625380 & 0.0236 \\
\hline LOG(CFGDP) & 0.784464 & 0.851490 & 0.4127 \\
\hline LOG(TDGDP) & 0.449899 & 0.439760 & 0.6686 \\
\hline $\mathrm{C}$ & 13.20255 & 9.271431 & 0.0000 \\
\hline
\end{tabular}

Source: Using E-views based on annex (1) and (2)

Using the E-views program, the most important indicators of financial development were estimated on the financial market indicators through Table (2). 
Table 2. The most influential indicators on the main sectors indicators.

\begin{tabular}{|c|c|c|c|c|c|}
\hline Dependent Var & AMIX) The most ir & ndicators on & ce sector index & 1 & \\
\hline Variable & Coefficient & t- Statistic & Prob & & \\
\hline LOG(LMI) & -4.426142 & -5.225363 & 0.0001 & & \\
\hline LOG(TSGDP) & 0.248607 & 5.774212 & 0.0000 & & \\
\hline $\mathrm{C}$ & 13.31040 & 13.47814 & 0.0000 & & \\
\hline Adjusted R-Squ & Squared: $=\% 8 \mathrm{D}-\mathrm{W}$ & ange $00.0 \quad \mathrm{~F}$ & & & \\
\hline LOG(AMIX) $=$ & 426142 LOG(LMI) & LOG(TSGD & & & \\
\hline Dependent Var & AMSX ) The most & indicators 0 & e sector index & 2 & \\
\hline Variable & Coefficient & t- Statistic & Prob & & \\
\hline LOG(TMI) & -2.474711 & 5.774212 & 0.0029 & & \\
\hline LOG(LMI) & -2.771770 & -5.225363 & 0.0009 & & \\
\hline LOG(TSGDP) & 0.170475 & & 0.0008 & & \\
\hline $\mathrm{C}$ & 11.44867 & 13.47814 & 0.0000 & & \\
\hline Adjusted R-Squ & Squared: $=\% 81 \mathrm{~F}=2$ & $=2.75 \operatorname{sig~F~c~}$ & & & \\
\hline LOG(AMSX) & 474711 LOG(TMI) & LOG(LMI) + & OG(TSGDP) & & \\
\hline Dependent Var & AMBX )) The mos & al indicators & ing sector index & 3 & \\
\hline Variable & Coefficient & t- Statistic & Prob & & \\
\hline LOG(TMI) & -4.410068 & -3.649138 & 0.0029 & & \\
\hline LOG(LMI) & -7.877886 & -6.781495 & 0.0000 & & \\
\hline LOG(TSGDP) & 0.194004 & 2.773503 & 0.0158 & & \\
\hline $\mathrm{C}$ & 18.63859 & 13.69493 & 0.0000 & & \\
\hline Dependent Var & (AMIDX) The mo & ial indicators & istry sector index & 4 & \\
\hline Variable & Coefficient & t- Statistic & Prob & & \\
\hline LOG(TMI) & -3.388797 & -3.548760 & 0.0036 & & \\
\hline LOG(LMI) & -3.391149 & -3.694440 & 0.0027 & & \\
\hline LOG(TSGDP) & 0.249951 & 4.522281 & 0.0006 & & \\
\hline $\mathrm{C}$ & 12.66307 & 11.77530 & 0.0000 & & \\
\hline Adjusted R-Squ & Squared: $=\% 79 \mathrm{~F}=2$ & $=2.02 \operatorname{sig} \mathrm{F} \mathrm{c}$ & & & \\
\hline LOG(AMIDX) & 388797LOG(TMI) & $\mathrm{OG}(\mathrm{LMI})+$ & G(TSGDP) & & \\
\hline Dependent Var & (AMGNRLX) The & uential indice & general Amman s & xchange index & 5 \\
\hline Variable & Coefficient & t- Statistic & Prob & & \\
\hline LOG(TMI) & -4.410068 & -3.649138 & 0.0029 & & \\
\hline LOG(LMI) & -7.877886 & -6.781495 & 0.0000 & & \\
\hline LOG(TSGDP) & 0.194004 & 2.773503 & 0.0158 & & \\
\hline $\mathrm{C}$ & 18.63859 & 13.69493 & 0.0000 & & \\
\hline Adjusted R-Squ & quared: $=\% 81 \mathrm{~F}=2$ & hange $00.0 \mathrm{I}$ & riable & & \\
\hline LOG(AMGNRI & 6-1.828948LOG(T) & 74LOG(LM) & LG(TSGDP) & & \\
\hline
\end{tabular}

Source: Using E-views based on annex (1) and (2) 


\section{Discussion of Statistical Analysis}

From Table (1): The researcher notes the following

The impact of the financial development indicators on the insurance sector index, where there is no statistically significant impact of the indicators of financial development (monetary total) Money supply (m2) to GDP $\{\mathrm{TMI}\}$ The Private Credit Index to GDP (CFGDP) and Total Deposits to GDP (TDGDP) On the Insurance Sector Index (AMEX) the reason for the increase in surplus cash reserves in the insurance sector because the above indicators reflect the increase in cash directed to the borrowing from the banking system and the insurance sector does not need borrow.

The impact of the financial development indicators on Service Sector Index( AMSX), where there is no statistically significant impact of the indicators of financial development The Private Credit Index to GDP (CFGDP) and Total Deposits to GDP (TDGDP) On the services sector index because the above indicators reflect the increase in cash directed to the borrowing from the banking system But the service sector depends on finance through the financial market, not banks because The sector needs long-term financing for expansion and growth.

The impact of the financial development indicators on Banking sector index (AMBX), where there is no statistically significant impact of the indicators of financial development The Private Credit Index to GDP (CFGDP) and Total Deposits to GDP (TDGDP) On Banking sector index (AMBX) because increased liquidity in the banking sector in Jordan.

The impact of the financial development indicators on Industry Sector Index (AMIDX), where there is no statistically significant impact of the indicators of financial development The Private Credit Index to GDP (CFGDP) and Total Deposits to GDP (TDGDP) On Industry Sector Index (AMIDX) because the above indicators reflect the increase in cash directed to the borrowing from the banking system But Industry Sector depends on finance through the financial market, not banks because The sector needs long-term financing for expansion and growth.

The impact of the financial development indicators on General Indicator index ( AMGNRLX), where there is no statistically significant impact of the indicators of financial development The Private credit index to GDP (CFGDP) and Total Deposits to GDP (TDGDP) On General Indicator (AMGNRLX) because the above indicators reflect are not statistically significant for the insurance sector index, the services sector index, the banking sector index and the industrial sector index .Accordingly, the researcher has reanalyzed the estimation of the most influential indicators on indicators of the main sectors, as it's shown in table (2).

The results of standard estimation of models, is that the value of total money's coefficient, has a negative indication, which means that the total monetary index is affecting negatively the service sector index, the Banking
Sector Index, the Industry Sector Index and the General Index. As well as liquidity index had a negative indication, which means that this index is affecting negatively the service sector index, the Banking Sector Index, the Industry Sector Index and the General Index; due to the increase of total monetary index (TMI)and liquidity index (LMI), where the currency in terms of trading and demand deposits and semi-cash, which is one of the monetary supply components in generalized concept, considering that the semi-cash is (term and saving deposits) and it's increase could lead to decrease monetary directed to main sectors; for example, monetary could be saved in banks instead of being an investment in main sectors, necessarily it will affect them negatively.

Moreover, standard estimation of the modal showed a positive indication of the value of traded shares in financial market to gross domestic product (TSGDP), which means that there is a positive correlation between changing in the ratio of traded shares in financial market to (GDP) and the changing in the main sectors' values; due to the increase of traded shares' value during years of the study, the thing that caused increase in investments in Amman Stock Exchange and necessarily the increase of main sectors' indicators. According to T-Test's experiences, these results have the statistical significance of the most influential financial indicators on the sector's key indicators.

The researcher makes some procedures to check the test stability and validity; through testing the tests and graphs below in Figure 4, and the bias proportion was zero. While, variance proportion and the covariance proportion indicate that the error is random and the anticipation capacity of the forms in Amman stock share is acceptable.

In addition, it has been agreed upon that there is a positive statistical correlation between indicators of financial development and the index of the insurance sector, services sector index, banking sector index, industrial sector index and general of Amman stock Exchange. However, it has been rejected that there is a statistically significant positive correlation between the indicators of financial development (total monetary index, liquidity index, total private credit index to GDP and total deposits to GDP index) and main sector's indices (insurance sector index, Services Sector Index, Banks Sector Index, Industry Sector Index and Amman Stock Exchange (General Index).

\section{Results}

- There is no statistically affect between the indicators of financial development (total private credit on GDP, total deposits to GDP), and indicators of main sectors (insurance sector index, services sector index, banking sector index, and the general index of Amman Stock Exchange), as well as there is no statistically significant effect between the total monetary index and the insurance sector index. 
- There is a positive effect of statistical significance between the index of the ratio of traded shares value in the financial market to GDP and indicators of main sectors. Due to the increase of traded shares value in financial market to gross domestic product, which causes the activity in financial market and increases values of Amman Stock Exchange's main sectors.

- There is a significant negative impact between the liquidity index and the main indicators for the following sectors (insurance sector index, insurance sector index, banking sector index, industry index and general index in the Amman Stock Exchange). The reason for this can be attributed to the fact that cash liquidity is a monetary supply in the broad sense to the monetary supply in the strict sense, in other words, the currency in terms of trading and demand deposits and semi-cash, which is one of the monetary supply components in broad sense, considering that the semi-cash is (term and saving deposits) and it's increase could lead to decrease monetary directed to main sectors.

- There is a negative significant impact between the total monetary index and the main indicators for the following sectors (Services Sector Index, Banks Sector Index, Industry Sector Index, and General Index of Amman Stock Exchange). The reason for this can be attributed to the fact that the increase of the increase of total monetary index, which is the same of monetary supply in broad sense to gross domestic product, as the currency in terms of trading and demand deposits and semi-cash, which is one of the monetary supply components in broad sense, considering that the semi-cash is (term and saving deposits) and it's increase could lead to decrease monetary directed to main sectors.

- The banking sector index has the highest average for indicators of Jordan's financial market, which amounted to $(47,3494)$ due to the role of the sector, as well as its importance in Jordan's financial market. At the second level was the insurance sector index with an amount of (47.2389) comparing to previous amount (2256.15), then the industrial index with amount of (2066.86), and finally the services sector index with amount of (1682.64) during years of the study.

- Monetary liquidity index has the highest average of financial improvement's indicators in Jordan's financial market, which amounted to (3.32), then the total monetary index with an average of (1.22), then the total credit to GDP (0.88). While the ratio of total deposits to GDP was $(75 \%)$ and the total value of traded shares for the listed companies as a percentage of GDP was (47\%) as the lowest among the indicators during years of the study.

\section{Recommendations}

- Activating the impact of financial development indices and total private credit on GDP by directing credit to the real private sector, will affect the activity of financial market and thus the effectiveness of main sectors indicators in Jordan's financial market.

- Activating the index of the of total deposits to gross domestic product through directing deposits in banks to real investment that leads to activation of financial market and thus the indicators of main sectors in Jordan's financial market.

- In terms of the ratio of shares traded in the financial market to GDP, we must work more effectively by attracting more international and regional foreign capital, especially from the Arab Gulf countries, which lead to increased activity in the financial market, and with more positive influence on key sector indices in the financial market.

- In terms of the liquidity index, we shall focus on reversing the negative impact to an affective positive one, by directing deposits in banks to real investment, which leads to a positive impact on the activity of financial market and then necessarily the indicators of main sectors in Jordan's financial market.

- In terms of total monetary index, we shall focus on reversing the negative impact to an affective positive one, by directing deposits in banks to real investment, which leads to a positive impact on the activity of financial market and then necessarily the indicators of main sectors in Jordan's financial market.

- According to indicators of Jordan's financial market, the role of banks shall be activated as the largest sector and the focus on influencing the activity of financial market and influencing other indicators, by supplying more funding to investment using non-conventional, innovative and acceptable financial instruments. Such as modern Islamic financial instruments, such as Sukuk, which stimulate real and financial investment and thus increase main financial indices and other major sectors in Jordan's financial market.

- Finding a financial market for Islamic financial instruments in Jordan's financial market in order to attract more capital from investors who want to invest in such type of tools. 


\section{Appendixes}

Table 3. Estimating the indicators of financial development during the years of study

\begin{tabular}{|c|c|c|c|c|c|}
\hline Years & $\begin{array}{l}\text { Total monetary } \\
\text { index (M2/GDP) } \\
(\mathrm{TMI})\end{array}$ & $\begin{array}{l}\text { Monetary liquidity } \\
\text { index } \\
\text { (M1/M2) } \\
\text { (LMI) }\end{array}$ & $\begin{array}{l}\text { Total value of traded shares of listed } \\
\text { companies to the gross domestic } \\
\text { product. (TS/GDP) } \\
\text { (TSGDP) }\end{array}$ & $\begin{array}{l}\text { Total credit index } \\
\text { to gross domestic } \\
\text { product. } \\
\text { (CF/GDP) } \\
\text { (CFGDP) }\end{array}$ & $\begin{array}{l}\text { Total deposits index } \\
\text { to gross domestic } \\
\text { product } \\
\text { (TD/GDP) } \\
\text { (TDGDP) }\end{array}$ \\
\hline 2000 & 1.23 & 3.6 & 0.05 & 0.83 & 0.70 \\
\hline 2001 & 1.23 & 3.7 & 0.10 & 0.81 & 0.73 \\
\hline 2002 & 1.23 & 3.63 & 0.13 & 0.81 & 0.71 \\
\hline 2003 & 1.30 & 3.24 & 0.25 & 0.84 & 0.68 \\
\hline 2004 & 1.30 & 3.31 & 0.46 & 0.85 & 0.70 \\
\hline 2005 & 1.38 & 3.04 & 1.89 & 0.93 & 0.82 \\
\hline 2006 & 1.32 & 3.08 & 1.33 & 0.88 & 0.87 \\
\hline 2007 & 1.28 & 3.22 & 1.02 & 0.87 & 0.88 \\
\hline 2008 & 1.17 & 3.28 & 1.30 & 0.85 & 0.79 \\
\hline 2009 & 1.18 & 3.31 & 0.57 & 0.93 & 0.76 \\
\hline 2010 & 1.18 & 3.40 & 0.35 & 0.93 & 0.74 \\
\hline 2011 & 1.17 & 3.31 & 0.14 & 0.93 & 0.74 \\
\hline 2012 & 1.13 & 3.45 & 0.09 & 0.80 & 0.73 \\
\hline 2013 & 1.14 & 3.25 & 0.12 & 0.88 & 0.72 \\
\hline 2014 & 1.14 & 3.16 & 0.08 & 0.94 & 0.69 \\
\hline 2015 & 1.18 & 3.19 & 0.13 & 0.97 & 0.69 \\
\hline 2016 & 1.19 & 3.16 & 0.08 & 0.94 & 0.74 \\
\hline
\end{tabular}

The researcher calculated indicators based on the data of Annex No. 3

Table 4. Main sector indicators during the years of study

\begin{tabular}{|l|l|l|l|l|l|}
\hline Years & $\begin{array}{l}\text { Insurance sector } \\
\text { index (AMIX) }\end{array}$ & $\begin{array}{l}\text { Service sector index } \\
\text { (AMSX) }\end{array}$ & $\begin{array}{l}\text { Banking sector } \\
\text { index } \\
\text { (AMBX) }\end{array}$ & $\begin{array}{l}\text { Industrial sector index } \\
\text { [AMIDX] }\end{array}$ & $\begin{array}{l}\text { General index (Stock Exchange } \\
\text { Index). [AMGNRL] }\end{array}$ \\
\hline 2000 & 920.35 & 915.1 & 795.54 & 774.24 & 813.34 \\
\hline 2001 & 943.63 & 975.75 & $1,147.02$ & 940.16 & $1,060.58$ \\
\hline 2002 & $1,044.62$ & 963.75 & $1,075.24$ & $1,065.26$ & $1,090.88$ \\
\hline 2003 & $1,609.88$ & $1,268.91$ & $1,995.77$ & $1,590.30$ & $1,556.27$ \\
\hline 2004 & $2,680.19$ & $1,762.03$ & $3,407.80$ & $2,344.46$ & $2,729.10$ \\
\hline 2005 & $5,738.65$ & $2,259.36$ & $6,171.34$ & $2,815.60$ & $4,259.71$ \\
\hline 2006 & $3,715.51$ & $1,833.05$ & $4,237.65$ & $2,372.33$ & $3,013.66$ \\
\hline 2007 & $3,690.07$ & $2,460.32$ & $5,122.20$ & $3,097.74$ & $3,674.96$ \\
\hline 2008 & $3,231.07$ & $2,025.56$ & $4,196.26$ & $2,736.01$ & $2,758.44$ \\
\hline 2009 & $2,837.97$ & $2,107.91$ & $3,646.76$ & $2,738.83$ & $2,533.54$ \\
\hline 2010 & $2,330.05$ & $1,897.16$ & $3,926.54$ & $2,576.59$ & $2,373.58$ \\
\hline 2011 & $2,089.81$ & $1,693.73$ & $3,475.33$ & $2,149.91$ & $1,995.13$ \\
\hline 2012 & $1,887.18$ & $1,651.12$ & $3,407.64$ & $2,176.57$ & $1,957.60$ \\
\hline 2013 & $1,793.17$ & $1,665.00$ & $3,888.82$ & $1,964.91$ & $2,065.83$ \\
\hline 2014 & $1,976.30$ & $1,794.77$ & $4,286.50$ & $1,852.02$ & $2,165.46$ \\
\hline 2015 & $2,064.58$ & $1,726.73$ & $4,249.67$ & $1,848.84$ & $2,136.32$ \\
\hline 2016 & $2,073.37$ & $1,604.67$ & $4,376.00$ & $2,092.99$ & $2,170.29$ \\
\hline
\end{tabular}

Source: https://sa.investing.com/indices/amgnrlx-historical-data 
Table 5. Data of the financial development index during the years of study. Per Million dinars

\begin{tabular}{|c|c|c|c|c|c|c|}
\hline Years & $\begin{array}{c}\text { Monetary supply in } \\
\text { broad sense (M2) }\end{array}$ & $\begin{array}{c}\text { Monetary supply in } \\
\text { strict sense (M2) }\end{array}$ & Total credit & $\begin{array}{c}\text { Total value of traded } \\
\text { shares of listed companies }\end{array}$ & $\begin{array}{c}\text { Total } \\
\text { deposits }\end{array}$ & $\begin{array}{c}\text { Gross domestic } \\
\text { product }\end{array}$ \\
\hline 2000 & 7434.7 & 2026.7 & 4221.4 & 334.724633 & 5000.2 & 5998.6 \\
\hline 2001 & 7866.1 & 2119.7 & 4691.5 & 668.652674 & 5203.7 & 6363.7 \\
\hline 2002 & 8419.1 & 2316.2 & 4848 & 950.272995 & 5532.6 & 6794 \\
\hline 2003 & 9465.7 & 2919.9 & 4957.3 & 1855.176028 & 6082.9 & 7228.8 \\
\hline 2004 & 10571.4 & 3192.9 & 5733.2 & 3793.25105 & 6878.7 & 8090.7 \\
\hline 2005 & 12364 & 4061.3 & 7327 & 16871.05195 & 8364.5 & 8925.4 \\
\hline 2006 & 14109.7 & 4566.5 & 9294.8 & 14209.87059 & 9427.1 & 10675.4 \\
\hline 2007 & 15606.8 & 4833.1 & 10705.5 & 12348.10191 & 10618 & 12131.4 \\
\hline 2008 & 18304.2 & 5573 & 12405.7 & 20318.01455 & 13348.5 & 15593.4 \\
\hline 2009 & 20013.3 & 6039.5 & 12986.6 & 9665.310642 & 15865 & 16912.2 \\
\hline 2010 & 22306.7 & 6550 & 13999.2 & 6689.987155 & 17617.2 & 18762 \\
\hline 2011 & 24118.9 & 7271.5 & 15258 & 2850.252628 & 19119.1 & 20476.6 \\
\hline 2012 & 24945.1 & 7211.1 & 16229 & 1978.813878 & 17711.1 & 21965.5 \\
\hline 2013 & 27363.4 & 8408.4 & 17387.1 & 3027.255186 & 21003 & 23851.6 \\
\hline 2014 & 29240.4 & 9231.7 & 17786.1 & 2263.404594 & 24013.1 & 25437.1 \\
\hline 2015 & 31605.5 & 9880.2 & 18575.2 & 3417.07903 & 26014.5 & 26637.4 \\
\hline 2016 & 32876.2 & 10386.9 & 20381.1 & 2329.46613 & 25968.2 & 5998.6 \\
\hline
\end{tabular}

Source: http://statisticaldb.cbj.gov.jo 

of the Main Sectors in Amman Stock Exchange during the Period [2000-2016]

LMI

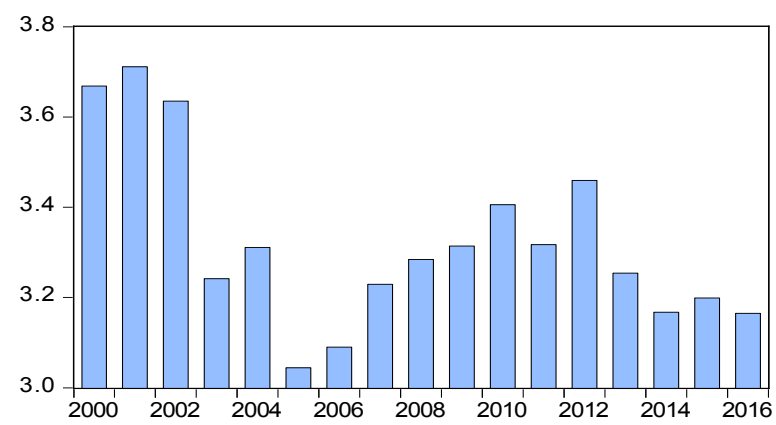

TSGDP

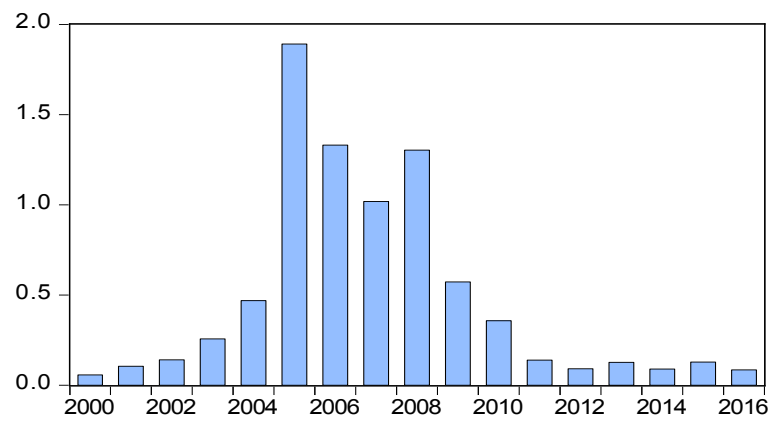

TDGDP

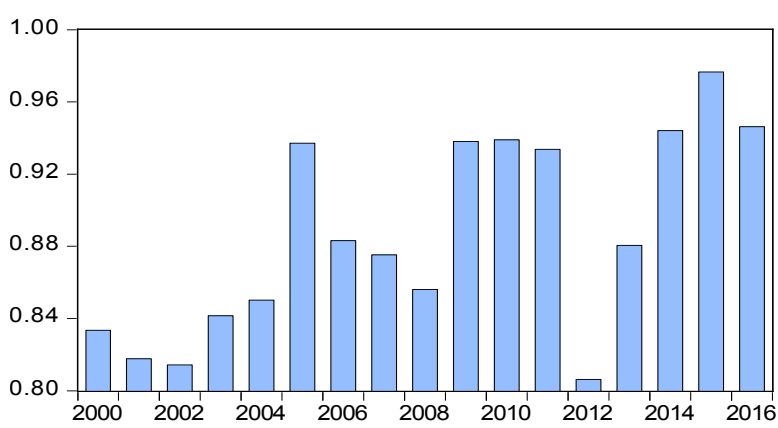

TMI

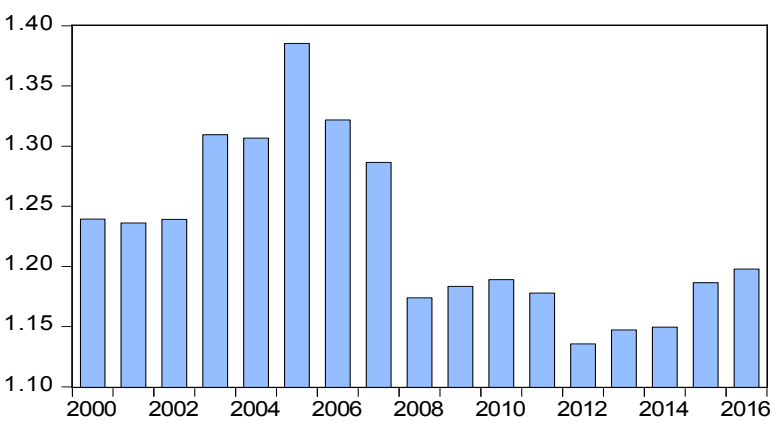

CFGDP

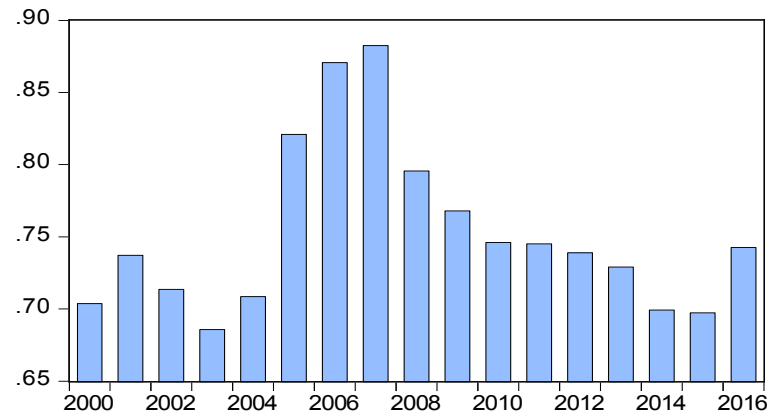

Source: Using E-views based on annex (3)

Figure 2. Chart of the Indicators of financial development during the years of stud 
$\mathrm{AMBX}$

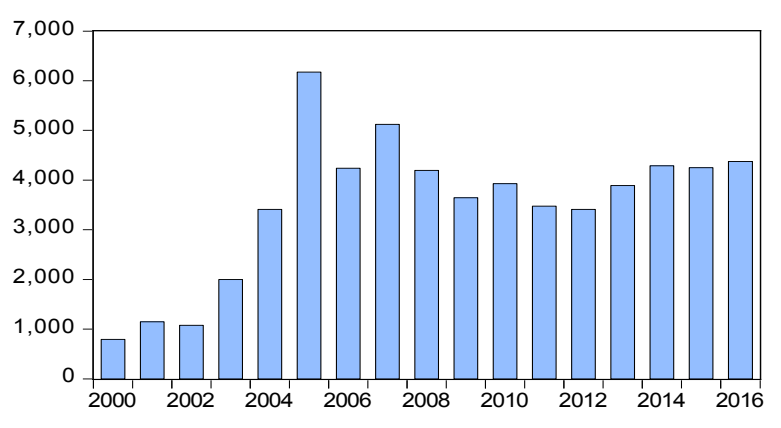

AMIDX

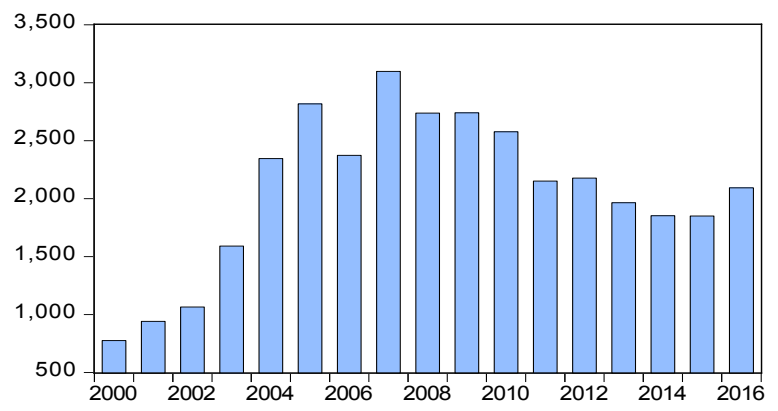

AMSX

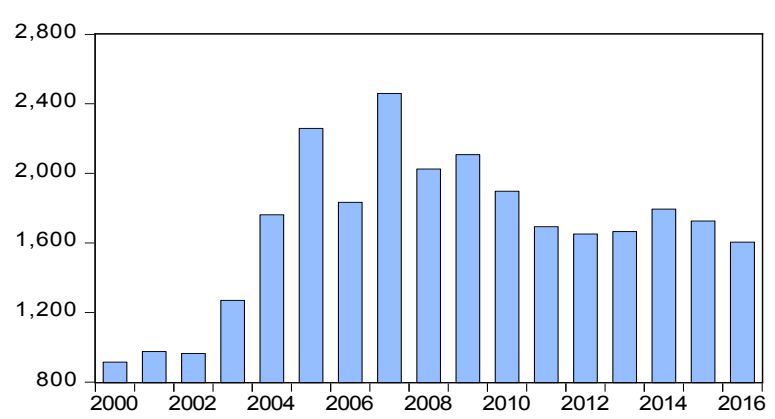

AMGNRLX

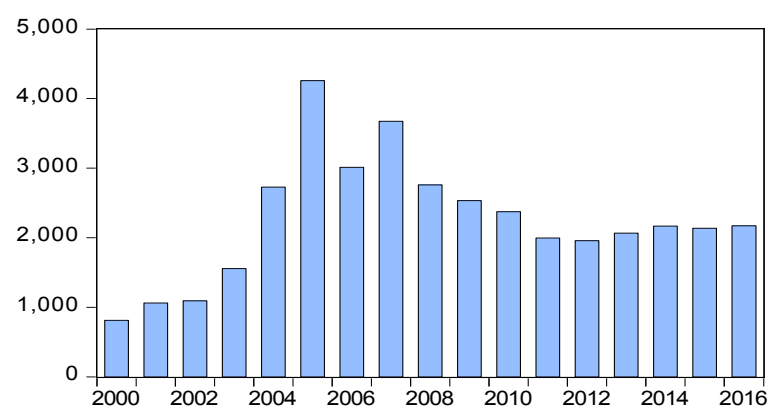

AMIX

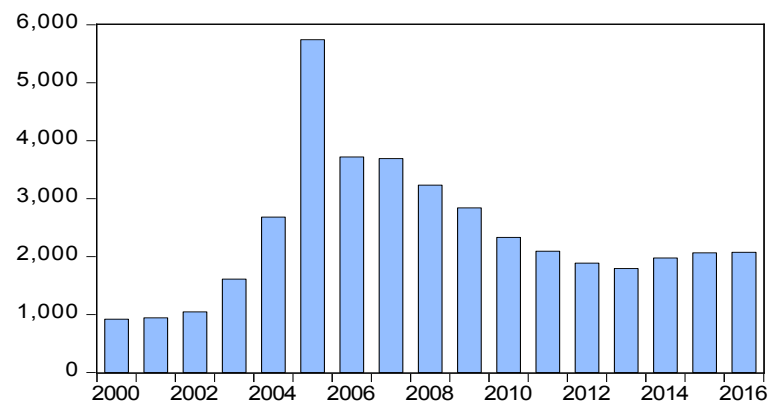

Source: Using E-views based on annex (4)

Figure 3 Chart of the main indicators of sectors in the financial market during the years of study

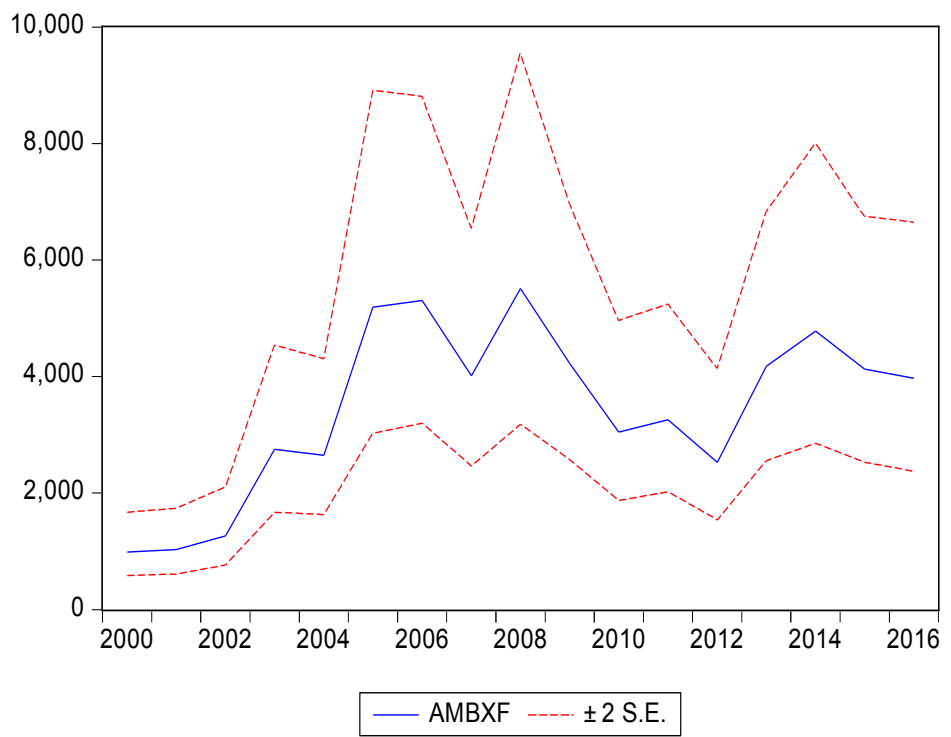

\section{Forecast: AMBXF}

Actual: AMBX

Forecast sample: 20002016

Included observations: 17

Root Mean Squared Error $\quad 717.8513$

Mean Absolute Error

Mean Abs. Percent Error

609.7602

18.11580

Theil Inequality Coefficient

Bias Proportion

0.095658

Variance Proportion

Covariance Proportion 

of the Main Sectors in Amman Stock Exchange during the Period [2000-2016]

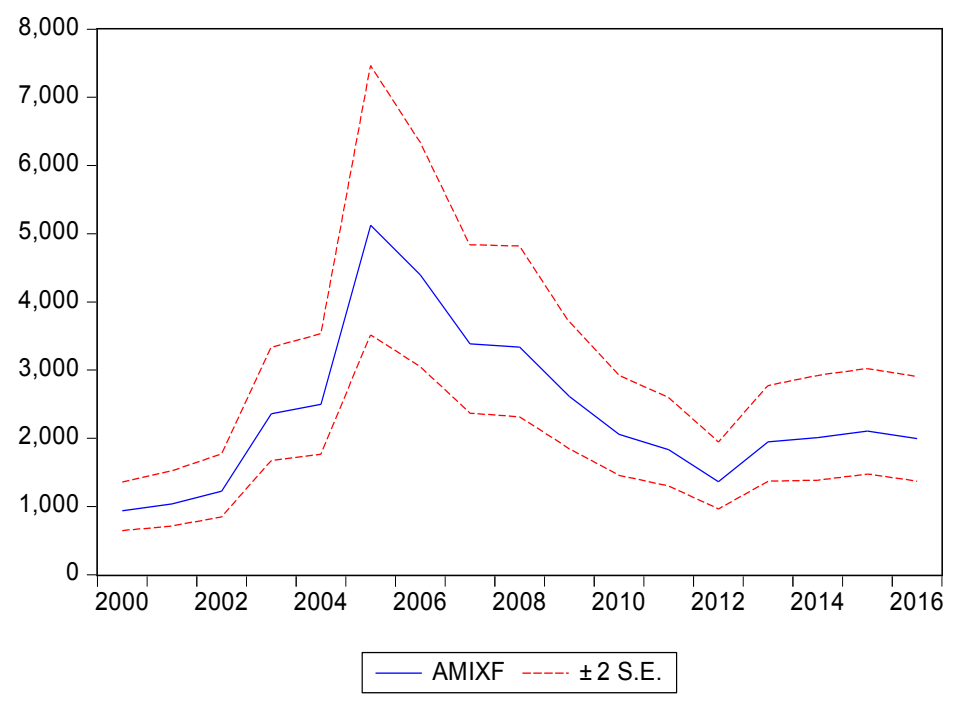

\section{Forecast: AMIXF \\ Actual: AMIX}

Forecast sample: 20002016

Included observations: 17

Root Mean Squared Error $\quad 350.0624$

Mean Absolute Error

265.8107

Mean Abs. Percent Error

11.68715

Theil Inequality Coefficient

0.066381

Bias Proportion

0.004705

Variance Proportion

0.037807

Covariance Proportion

0.957489

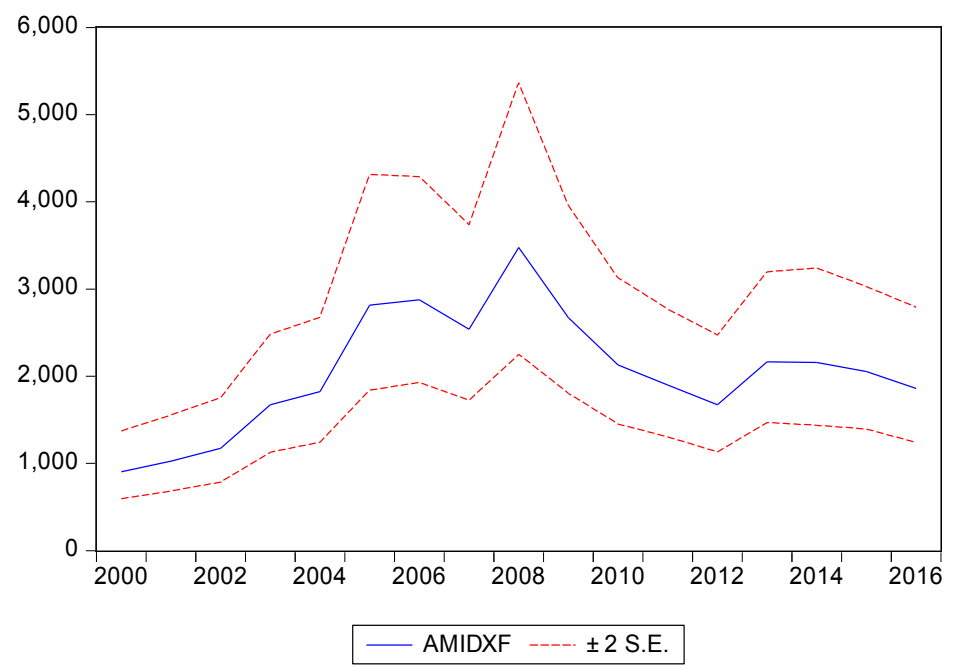

\section{Forecast: AMIDXF}

Actual: AMIDX

Forecast sample: 20002016

Included observations: 17

Root Mean Squared Error

Mean Absolute Error

358.2348

Mean Abs. Percent Error

0698

Theil Inequality Coefficient

Bias Proportion

13.73961

Variance Proportion

0.082829

Covariance Proportion

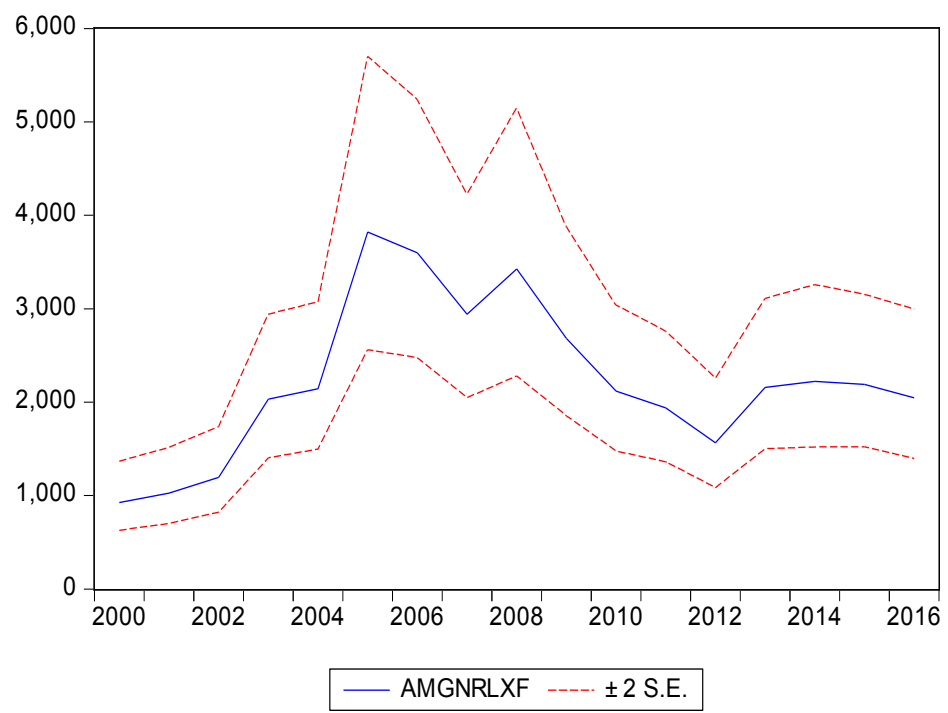

Forecast: AMGNRLXF

Actual: AMGNRLX

Forecast sample: 20002016

Included observations: 17

Root Mean Squared Error

Mean Absolute Error

Mean Abs. Percent Error

Theil Inequality Coefficient

Source: Using E-views based on annex (3 and (4)

Figure 4. Test the ability of models to predict 


\section{REFERENCES}

[1] Abdul salam Abu bakar, Ibrahim Musa Gani(2013), Impact of Banking Sector Development on Economic Growth: Another Look at the Evidence from Nigeria,Journal of Business Management \& Social Sciences Research, Volume 2, No.4, ISSN No: 2319 - 5614.

[2] Andrés Fernandez César E.(2015), Tamayo From Institutions to Financial Development and Growth:IDB Working paper series No. IDB-WP-565, IDB-WP-565 Department of Research and Chief Economist IDB series No. IDB-WP-565 Inter-American Development Bank.

[3] Charles Wait and TafadzwaRuzive,(2016), The Influence of Financial Market Development on Economic Growth in BRICS Countries, Economic Research Southern Africa (ERSA) is a research program funded by the National Treasury of South Africa ,ERSA working paper 625.

[4] DynaHeng, Anna Ivanova, Rodrigo Mariscal, Uma Ramakrishnan, and Joyce Cheng Wong,(2016), Financial Development in Latin America and the Caribben, IMF Working Papers describe research an WP/16/81.

[5] Evans OchoroOlonje(2014), The Relationship Between Financial Market Development and Economic Growth In East African Community Research Project Submitted In Partial Fulfillment OF The Requirements of The A ward Of The A ward OF The Degree of Master of Business Administration, School of Business ,University of Nairobi.

[6] George Adu and George Marbuah, Justice Tei Mensah, Financial development and economic growth in Ghana: Does the measure of financial development matter?,(2013), Review of Development Finance, Volume 3, Issue 4, Pages 192-20

[7] HamiMahyar (2017), The Effect OF Inflation on Financial development Indicators In Iran (2000-2015), Studies In Business and Economics NO12(2).

[8] Laura Alfaro, Sebnem Kalemli-Ozcan and Selin Sayek, (2009), Productivity and Financial Development The World Economy (2009) doi: 10.1111/j.1467-9701.2008.01159.x. (C) 2009 The Authors Journal compilation (C) 2009 Blackwell Publishing Ltd, 9600 Garsington Road, Oxford, OX4 2DQ, UK and 350 Main Street, Malden, MA 02148, USA..

[9] Léonce Ndikumana ,(2003),Financial Development, Financial Structure, and Domestic Investment: International Evidence ,LéonceNdikumana Department of Economics University of Massachusetts Thompson Hall, Box 37510 Amherst, MA 01003 Fax: (413) 545-2921.

[10] Mohamed Abdel Karim Bogaza, (2015), Financial Development in the Maghreb Countries in the Opening and Financial Liberalization during Period (1990-2013), Journal of the Performance of Algerian Institutions, No. 8.

[11] Mohammed Issa Shehatait, Saud Musa al-Tayeb and Qusay Mohammed al-Tarouna,(2014) The impact of the Amman Stock Exchange on investment in Jordan, Studies, Administrative Sciences, vol. 41, no. 1

[12] Musharavati Ephraim Munyanyi, dynamic relationship 